\section{Cytokine milieu in Undifferentiated Connective Tissue Disease: A comprehensive} review

\section{Britt Nakken PhD ${ }^{1}$, Edit Bodolay MD $\mathrm{PhD}^{2}$ and Peter Szodoray MD PhD ${ }^{1}$}

${ }^{1}$ Institute of Immunology, Rikshospitalet, Oslo University Hospital, Oslo, Norway

${ }^{2}$ Department of Clinical Immunology, Institute of Medicine, University of Debrecen Medical and Health Science Centre, Debrecen, Hungary

Address for correspondence and reprint request:

Peter Szodoray MD, $\mathrm{PhD}$

Institute of Immunology, Rikshospitalet, Oslo University Hospital

Sognsvannsveien 20. Oslo, Norway, N-0027

Phone: + 4723073065

Fax: + 4723073510

Email: szodoray@gmail.com 


\section{ABSTRACT}

Undifferentiated connective tissue disease (UCTD) is a unique clinical entity, a potential forerunner of well-established systemic autoimmune/rheumatic diseases. UCTD is characterized by the presence of various clinical symptoms, as well as a diverse repertoire of autoantibodies, resembling systemic autoimmune diseases. Since approximately one-third of these patients consequently transform into a full-blown systemic autoimmune/rheumatic disease, it is of major importance to assess pathogenic factors leading to this progression. In view of the fact that the serological and clinical picture of UCTD and systemic autoimmune diseases are very similar, it is assumed that analogous pathogenic factors perpetuate both disease entities. In systemic autoimmune conditions a quantitative and qualitative impairment of regulatory $\mathrm{T}$ cells have been shown previously and in parallel a relative dominance of proinflammatory Th17 cells has been introduced. Moreover the imbalance between regulatory and Th17 cells plays a pivotal role in the initiation and propagation of UCTD. Additionally, we depict a cytokine imbalance, which give raise to a biased T-cell homeostasis from the UCTD phase throughout the fully developed systemic autoimmune disease stage. The levels of IL-6, IL-12, IL-17, IL-23 and IFN- $\gamma$ were pathologically increased with a parallel reduction of IL-10. We believe that the assessment of Th17/Treg cell ratio, as well as the simultaneous quantitation of cytokines may give a useful diagnostic tool at the early UCTD stage to identify patients with a higher chance of consecutive disease progression towards serious systemic autoimmune diseases. Moreover, the early-targeted immunomodulating therapy in these patients may decelerate, or even stop this progression, before the development of serious autoimmune conditions with organ damage. 


\section{KEYWORDS}

Undifferentiated connective tissue disease, systemic autoimmune diseases, regulatory $\mathrm{T}$ cells, Th17 cells, cytokine imbalance, disease progression 


\section{Undifferentiated connective tissue disease (UCTD)}

Undifferentiated connective tissue disease (UCTD) is a unique clinical entity, a potential forerunner of a subsequentially developing full-blown systemic autoimmune/rheumatic disease. UCTD is characterized by the presence of various clinical symptoms, resembling rheumatic diseases, as well as a diverse repertoire of autoantibodies. The most common clinical symptoms of the disease include Raynaud's phenomenon, fever, arthritis, serositis, (pleuritis, pericarditis), sicca symptoms, skin involvement (photosensitivity, rash), central and peripheral nervous system symptoms, vasculitis, pulmonary involvement, myositis, and accelerated atherosclerosis [1]. The serological abnormalities can include the presence of the following autoantibodies: anti-nuclear (ANA), anti-dsDNA, -Sm, -RNP, -SSA, -SSB, -Scl-70, -centromere, -Jo1, or -PM-Scl, amongst others [1]. However, this clinical-serologic constellation does not fulfill the diagnostic criteria of any well-defined rheumatic, systemic autoimmune diseases, amongst others rheumatoid arthritis (RA), systemic lupus erythematosus (SLE), Sjögren's syndrome, idiopathic inflammatory myopathies (IIMs), mixed connective tissue disease (MCTD), or systemic sclerosis (SSc) [2-6]. The most important clinical feature of UCTD is that over one-third of these patients consequently transform into a full-blown systemic autoimmune/rheumatic disease [1]. In our previous study where we followed-up 665 UCTD patients for 5 years and showed that $34.5 \%$ of these patients developed a well-defined systemic autoimmune disease, with the following enddisease progressions: 38\% RA, 20\% Sjögren's syndrome, 12\% SLE, 11\% MCTD, 10 systemic vasculitis, $8 \%$ progressive SSc and 1\% IIMs [1]. The highest probability of evolution to a defined systemic autoimmune/rheumatic disease was during the first 2 years after onset. 


\section{The pathogenesis of UCTD}

As we have depicted previously UCTD both in clinical symptoms and serologically resembles systemic autoimmune diseases, which raises the possibility that similar factors are involved in the pathogenesis of these clinical entities. Moreover, since UCTD can be the forerunner of subsequentially developing rheumatic diseases it is plausible that the escalation and intricate interplay of certain pathogenic factors in the UCTD stage lead to disease progression. UCTD and fully developed systemic autoimmune diseases are typically multi-etiological entities, where genetic, environmental abnormalities along with derailed immunoregulatory processes contribute to the development of the disease. In the healthy immune system, various tolerance mechanisms, such as activation-induced cell death, the functional inertness, denoted as anergy, or clonal ignorance play a crucial role to prevent the activation of self-reactive lymphocytes [7]. In autoimmune conditions with faulty tolerance mechanisms, self-reactive lymphocytes may not be subjected to peripheral deletion, or anergy raising the possibility of the survival and activation of autoreactive $\mathrm{T}$ and $\mathrm{B}$ cells upon autoantigen encounter [8-10]. However, there is a fine line between autoimmune processes, which also appear in healthy individuals and manifested autoimmune diseases. In autoimmune diseases, one or several tolerance mechanisms permanently fail due to the constellation of various environmental factors, specific HLA- and non-HLA genes and derailed immunoregulatory processes, leading to the persistence of self-reactive $\mathrm{T}$ and $\mathrm{B}$ cell clones, and ultimately organ damage $[10,11]$. Since similar clinical and pathogenic features can be found between UCTD and developed systemic autoimmune diseases we hypothesized that immunoregulatory abnormalities and/or the imbalance of immunoregulatory and inflammatory processes at the UCTD stage could lead to the progression towards systemic autoimmune diseases. 


\section{The role of regulatory $T$ cells in systemic autoimmune diseases and UCTD}

The balance of pro- and anti-inflammatory mechanisms is crucial to maintain the antigenic integrity of the individual, yet must effectively eliminate pathogens. On the anti-inflammatory side, several characteristic cell populations exist, which have the capability to suppress immune and autoimmune processes once they have developed. One important group of such immunoregulatory cells is denoted as regulatory $\mathrm{T}$ cells (Tregs). Tregs derive either from the thymus $\left[\mathrm{CD} 4+\mathrm{CD} 25^{\text {bright }} \mathrm{FoxP} 3+\right.$ natural Tregs (nTregs)] or in the peripheral blood [IL-10, or TGF-b producing Type-1 regulatory T-cells (Tr1)] [12]. It is reasonable to speculate that when regulatory T-cells are reduced in numbers or functionally impaired, pro-inflammatory immune responses are evoked, and upon susceptible genetic background, autoimmune processes can occur, leading to the spontaneous development of various autoimmune diseases. In line with this hypothesis, previous studies conducted on patients with systemic autoimmune and rheumatic disease described that the selective decrease in the number of Tregs or, alternatively, a diminished suppressor function of Tregs are characteristic to these diseases (e.g. SLE, MCTD, Sjögren's syndrome or RA [13-17]. These data indicate that in patients with established autoimmune conditions a well-characterized quantitative and/or qualitative impairment of the regulatory T-cell pool exists.

As a natural follow-up to these findings, we previously investigated the regulatory $\mathrm{T}$ cell pool of patients with UCTD [18]. In these patients, the assessment of Treg cells showed that the percentage and absolute number of $\mathrm{CD} 4+\mathrm{CD} 25^{\text {bright }} \mathrm{FoxP} 3+$, natural Tregs were diminished in UCTD patients compared with healthy controls, while the number of CD4+IL10+, inducible Tregs was increased [18]. This progressive divergent shift in natural and induced T-regulatory cells clearly predicted the transition from the undifferentiated connective tissue disease to a well-established systemic autoimmune disease [18]. 
Interestingly, we and others have described that in patients with active systemic autoimmune diseases, such as SLE, or MCTD, the frequency of CD4+CD25 $5^{\text {bright }}$ FoxP3+ Tregs was found to be decreased compared to healthy individuals, or interestingly in patients with an inactive disease state $[13,15,19]$. The other major regulatory $\mathrm{T}$ cell subset, denoted as IL-10 producing Type-1 regulatory T-cells (CD4+IL-10+, Tr1) has been implicated in various autoimmune diseases [20]. IL-10 is a multifunctional cytokine that can suppress the IFN- $\gamma$ production of Th1 cells and regulate growth and/or differentiation of various T cell types, B cells, or NK cells [21,22]. In relation to this we discovered a significant increase in Tr1s when UCTD patients were compared with healthy controls, and we found further increase in patients who progressed into definitive systemic autoimmune diseases. This could be interpreted as a compensatory mechanism to down-modulate the effects of the observed IFN- $\gamma$ overproduction $[18]$.

\section{Th17 cells and the Th17/Treg ratio in systemic autoimmune diseases and UCTD}

On the pro-inflammatory side, T-cells have the ability to differentiate into IL-17-producing T helper cells, denoted as Th17 cells, and this differentiation is independent of Th1 or Th2 cell development [23,24]. Th17 cells recruit neutrophils and macrophages to the site of inflammation; therefore they are crucial in pro-inflammatory immunological processes, in the combat against pathogens, mostly against extracellular pathogens [24]. Dysregulated synthesis and increased levels of Th17 cells have been associated with numerous inflammatory conditions, as well as with autoimmune diseases. Amongst others, increased levels of IL-17 has been shown in the sera, synovial fluids and synovial biopsies of most RA patients, while osteoarthrosis, as a control, non-inflammatory population, showed no increased levels of this cytokine [25,26]. Furthermore, emerging data show a body of evidence that IL-17 and Th17 cells may play a role in the pathogenesis of SLE, and in lupus 
nephritis [27,28]. Regarding an important systemic autoimmune disease, in patients with the peripheral blood, and the cytokine can be found with increased levels in the affected salivary glands $[29,30]$.

It is interesting to speculate on what initiates and drives the shift in balance of the Th17 and regulatory T-cells in autoimmune conditions. Regulatory T-cells develop in the thymus and participate in the maintenance of peripheral tolerance. As we saw, in systemic autoimmune diseases the circulating and local skewed cytokine milieu alters the suppressive function of these cells [31]. In affected organs, at the histological site of inflammation, a cytokine imbalance is present, with a predominance of IL-6 and TGF-b, which favor the development of Th17 cells. Th17 cells are pivotal in the initialization and progression of inflammatory processes, rather than Tregs; in addition higher concentrations of TNF-a downmodulates the function of Tregs [31].

Since altered Th17 and regulatory $\mathrm{T}$ cell ratios may play a pathogenic role by tipping the fine balance toward enhanced immune reactivity, the disruption of this equilibrium has been studied in various systemic autoimmune conditions [32-35]. In order to assess whether a shift in the cytokine homeostasis exists in autoimmune conditions, fueling the predominance of pro-inflammatory cells vs. immunoregulatory T-cells, we have measured a broad spectrum of circulating cytokines in patients with various systemic autoimmune and rheumatic diseases [36-41]. 


\section{Cytokine imbalance, regulatory/effector cells in various well-defined systemic autoimmune and rheumatic diseases}

\section{Primary Sjögren's syndrome (pSS)}

\section{The clinical picture and immunocompetent-cell distribution of pSS}

Primary Sjögren's syndrome (pSS) is a chronic, slowly progressive, systemic autoimmune disease that predominantly affecting middle-aged women, although it can be seen in people of all ages, including children [42]. pSS is characterized by mononuclear infiltration and destruction of the exocrine glands, resulting in dry mouth, keratoconjunctivitis sicca and the presence of other exocrinopathic symptoms, affecting various organs [42]. In the pathogenesis, a variety of native and adaptive cellular and humoral autoimmune processes have been described previously $[42,43]$. On the adaptive immune system's side, different subsets of T and B lymphocytes and monocytes contribute to the pathogenesis. Increased cell activation, uncontrolled apoptotic processes, and immune response are partly driven by a skewed cytokine milieu contributing to the pathogenesis of the disease $[43,44]$. Besides intraglandular cytokines and chemokines, a group of peripheral cytokines, chemokines and growth factors have been implicated in the pathogenesis of $\mathrm{pSS}$, contributing to the perpetuation of the cellular and humoral autoimmune processes, leading to the pathognomonic clinical picture [44-47]. In our previous study we assessed how certain peripheral immune parameters reflect the inflammatory alterations in patients with pSS, determined lymphocyte subpopulations and their state of activation from peripheral blood, evaluating both soluble serum T-helper (Th)1/Th2-type cytokines, as well as intracytoplasmic cytokines [48]. We found that the skewed T-cell subsets and cytokine imbalance play important roles in an orchestrated proinflammatory cascade. Patients with pSS were characterized by elevated percentages of 
activated T cells (CD3+/CD69+ T lymphocytes), compared to healthy individuals [48]. The assessment of naïve vs. memory CD4+ and CD8+ T cells, we could identify a clear shift towards the memory phenotype in both $\mathrm{T}$ cell subsets. Th0 and Th1 cell numbers were increased in patients compared to controls. Concerning cells of the innate immune system, NK cell and NK T-cell percentages were elevated in pSS patients.

\section{Cytokine imbalance in the pathogenesis of pSS}

In order to shed light, which cytokines might be responsible for the aforementioned cellular shifts we measured serum cytokines in patients and healthy individuals in parallell. Interestingly we found that among circulating cytokines, interferon (IFN)-gamma was high, whereas interleukin (IL)-10 was decreased in patients with pSS [48]. In addition, us and others have evaluated changes in regulatory cells and a wide spectrum of serum cytokine in pSS patients which seemed beneficial to cluster and subgroup patients with pSS [30,41,49$51]$.

The great advantage of assessing various cytokines in patients with systemic autoimmune and rheumatic diseases is that the univariate and/or multivariate analyses of these cytokines aids to create and identify patient subsets in diseases, previously thought to be homogeneous. In line with this approach, we have previously showed that circulating cytokines have the ability to distinguish pSS patients with ectopic salivary gland germinal centers, a possible forerunner of lymphoma development in the disease $[30,41,50]$. In this study, univariate analysis demonstrated that serum levels of a broad spectrum of immune and inflammatory modulating cytokines are upregulated in both pSS patient groups (pSS patients with, or without ectopic germinal center formation), relative to unaffected controls: IL-1beta, IL-2, IL-6, IL-15, IFNgamma and CCL4 (MIP-1beta) [30]. pSS patients with ectopic germinal center formation were distinguished from healthy individuals by higher levels of IL-4, IL-10, GM-CSF, IFN- 
alpha, CCL3 (MIP-1alpha), CCL11 (Eotaxin) and B-cell activating factor (BAFF/BLyS),

\section{Systemic sclerosis}

Systemic sclerosis (SSc) is a systemic disease of autoimmune pathogenesis, characterized by excessive extracellular matrix deposition and damage of the small blood vessels. (SSc) is associated with endothelial cell dysfunction, where classically the microvasculature is affected. The hallmarks of the disease are inflammatory processes, dominantly in the skin and visceral organs, such as the heart, lungs, or kidneys [52,53]. The key role of the innate and adaptive immune system has been depicted in the pathogenesis of SSc [54-57]. Disorders of the immune system lead to chronic inflammatory processes, abnormal $\mathrm{T}$ cell activation, $\mathrm{B}$ cell abnormalities, abundant production of proinflammatory cytokines (e.g. IL-4), and the production of characteristic autoantibodies including anti-centromere antibodies in limited SSc and anti-topoisomerase 1 and anti-RNA polymerase I/III antibodies in diffuse SSc. Regulatory cells with impaired function have been shown to play a role in the initiation and 
perpetuation of the disease [56,57]. In SSc patients increased levels of circulating Th17 cell have been described, along with elevated IL-17 serum concentrations [58,59]. On the helper T cell side, an altered balance of the Th1 and Th2 cytokine profile may also be responsible for the development of fibrosis [60]. Previously we have depicted a wide spectrum of peripheral immune-competent cell types, reflecting overall disturbances in immune homeostasis, characteristic of systemic sclerosis [61]. We found that patients with SSc had higher percentages of activated T cells, reflected by increased ratio of CD3+/HLA-DR+ cells. Comparing naive vs. memory subsets of CD4+ and CD8+ T cells, a shift towards central memory phenotype was observed. We saw an imbalance of various immune-competent celltypes of the innate immune system characterized by abnormal levels of NK and NKT cells.

\section{Regulatory T-cells and the cytokine milieu in the pathogenesis of SSc}

We depicted a shift between the effector and regulatory T cell level in SSc. Increased Th-17 cell percentages, together with decreased levels of Th1, as well as regulatory $\mathrm{T}$ cell subsets, IL-10 producing Tr1 cells (CD4+IL-10+ T-cells), and CD4+CD25+FOXp3+ Treg cell were characteristic to these patients [61]. We also found decreased IL-10 levels in SSc. Besides the quantitative differences of regulatory cells between patients and controls, the functional assessment of Tregs identified that the suppressor activity of CD4+CD25+FOXP3+ Treg cells was clearly decreased in SSc, compared to healthy individuals. Our data suggest that the increased Th17/Treg ratio and the altered regulatory function of CD4+CD25+FOXP3+ Treg cells play an important role in the development and progression of SSc. Moreover, our study identified the potential role of the decreased presence of IL-10-producing Tr1 cells (along with lower IL-10 serum levels) in the progression of disproportionate immune responses in SSc [61]. Altogether these findings suggest that the assessment of regulatory immune- 
competent cells and peripheral cytokines aids in the understanding the pathogenesis of these autoimmune diseases. The Th17 cell and regulatory $\mathrm{T}$ cell imbalance, along with impaired circulating cytokine profile gives a good ground to use these parameters for therapy response assessment in SSc. Extracorporeal photochemotherapy (ECP) is a useful therapeutic modality in SSc, therefore we enrolled patients with diffuse cutaneous SSc, whom received 12 ECP treatments in total and assessed various immunocompetent celltypes, including regulatory cells and Th17 cells using intracellular cytokine staining [62]. We could see significant changes in these parameters following treatment. After a series of ECP, the percentages and numbers of peripheral Th17 cells decreased, we observed a clear increase in Tr1 and Treg cell numbers, and interestingly we could identify a functional improvement of Tregs, as reflected by the recovered suppressor capacity of Treg cells. Moreover, we found a positive correlation between the reduction of IL-17 levels and skin thickness, an objective measure of improvement in SSc. Concerning serum cytokines, chemokines and growth factors, levels of CCL2 and TGF-beta decreased, while the concentration of IL-10, IL-1-receptor-alpha, and hepatocyte growth factor elevated during the therapy [62]. ECP had a clear effect on lymphocyte activation. We observed a significant negative correlation between the changes in peripheral activated CD95+ T cell and CD4+CD25+ Treg cell levels. We found negative correlations between CD69+ and HLA-DR+ T cells and the functional ability of the CD4+CD25+ Treg cells following a series of ECP treatment. The initial increase of CD95+ expression in SSc reflects a state of lymphocyte activation during autoimmune processes, which can be effectively attenuated by the restoration of regulative $\mathrm{T}$ cell numbers and functions as the result of ECP therapy [63]. These results clearly indicate that the assessment of Th17 and regulatory $\mathrm{T}$ cell subsets along with soluble cytokines aids in the patient followup and therapy response monitoring in SSc 


\section{Mixed Connective Tissue Disease}

\section{Clinical picture, effector- and regulatory-T cell profile of MCTD patients}

In Mixed connective tissue disease (MCTD) the most frequently observed symptoms are arthritis, Raynaud's phenomenon, myositis, esophageal dysmotility, and acrosclerosis along with the presence of autoantibodies reactive with U1 small nuclear RNP (U1RNP) autoantigens [64-66]. Long-term follow-up studies reveal that other symptoms, such as serositis (pleuritis, pericarditis), pulmonary involvement, skin involvement, neuropsychiatric disease, and glomerulonephritis may also develop in this systemic autoimmune disease [6771]. Previously we assessed serum cytokines and intracellular cytokine production of CD4+ and CD8+ T cells in patients with MCTD [72]. Serum concentrations of both type 1 and type 2 cytokines were significantly higher in patients with MCTD than in healthy controls. In patients with active MCTD, the percentage of CD8+/IFN-gamma+, cytotoxic type-1 T lymphocytes was significantly increased compared to its level in inactive disease, or healthy individuals. IL-4 expression of CD4+ T cells (representing Th2 cells) was scarcely detectable in MCTD. A higher percentage of CD8+/IL-4+, cytotoxic type $2 \mathrm{~T}$ cells were detected in patients, especially in those with active disease, compared to controls. The percentage of IL10-producing CD4+ and CD8+ T cells was higher in patients than in controls. Again, CD4+ and CD8+ T cells from patients with active MCTD produced significantly more IL-10 than cells in patients with inactive disease or in healthy individuals [72]. These findings support the idea that MCTD is characterized by a wide spectrum of $\mathrm{T}$ cell abnormalities, which becomes explicit in the active phase of the disease. Concerning the role of immunoregulatory abnormalities in the pathogenesis, we assessed CD4+CD25+ regulatory $\mathrm{T}$-cells in patients with MCTD. In line with findings from patients with other systemic autoimmune, rheumatic 
diseases, the percentage and the absolute number of CD4+CD25+high Treg cells were lower in patients than in healthy controls which further decreased in patients with active disease. Interestingly, we saw an increase in the percentage and absolute number of CD4+IL-10+ $\operatorname{Tr} 1$ cells in patients with MCTD compared to healthy controls. The percentage of Tr1 cells was higher in the active stage of MCTD than in the inactive stage. The decrease in the number of CD4+CD25+high Treg cells in an important factor in the immunoregulatory disturbance in patients with MCTD. We believe that elevated Tr1 cell percentages could be a compensatory mechanism aiming to restore the balance between type 1 and type 2 cytokines in MCTD [73].

\section{Characterisation of serum cytokines and regulatory cells in MCTD}

As we discussed previously the assessment of regulatory cells and serum cytokine monitoring can be a useful tool in disease sub-categorization. In order to depict the value of cytokine measurement and regulatory cell assessment in MCTD, we investigate the frequency of sensorineural hearing loss (SNHL) in patients with MCTD and evaluated various immunological parameters in patients with, or without this inner ear disorder. Serum levels of IFN-gamma and TNF-alpha were increased in MCTD patients with SNHL compared to patients without SNHL. The absolute number of Tregs was lower compared to patients without SNHL. The decreased levels of regulatory T cells, along with the increased expression of pro-inflammatory cytokines may play a role in the pathogenesis of immune mediated inner ear disorders in MCTD [74].

In another approach in order to use cytokine assessment in disease profiling, we evaluated the vitamin D status in MCTD patients and assessed which clinical symptoms, laboratory parameters and endothelial cell markers are associated with low vitamin D levels. We found that vitamin D levels were inversely associated with serum IL-6, IL-23, and IL-10 cytokine levels, while low vitamin D levels were also significantly associated with carotid artery intima 
media thickness, fibrinogen, total cholesterol and ApoA1 levels. The presence of

\section{Systemic Lupus Erythematosus (SLE)}

\section{Clinical picture and pathogenesis}

SLE is a heterogeneous, multi-etiological systemic autoimmune disease with various organ involvements, encompassing mild to moderate forms, and also severe, progressive variants [76-78]. The organ manifestations of the disease include dermatologic signs, arthritis, and serositis, as well as renal, neurologic, and hematologic disorders. Serologically, lupus is characterized by the presence of antinuclear antibodies (80-90\% of patients), doublestranded DNA-directed autoantibodies (58-70\% of patients), and antibodies directed to other nuclear antigens, such as histones and small nuclear ribonucleoproteins (snRNP) in a minor group of patients.

\section{Cytokines and immune-regulatory defects}

Several cytokines have also been implicated in the pathogenesis of SLE, amongst others BAFF/BLyS, TNF- $\alpha$, IFN- $\alpha$, IFN- $\gamma$, IL-12, IL-23, IL-18, IL-6, IL-10 and IL-17 forming a rationale also for therapeutic intervention in the disease $[79,80]$.

Previous studies on gene polymorphisms in SLE risk genes identified the key roles of particular cytokines in the pathogenesis. Thus, an SLE risk haplotype of interferon regulatory 
factor-5, (IRF5) has been shown to be linked to the increased production of interferon (IFN)$\alpha$, and an autoimmune disease risk variant of signal transducer and activator of transcription 4 (STAT4) causes increased sensitivity to IFN- $\alpha$ in patients with SLE $[81,82]$. The protein, encoded by tumor necrosis factor alpha-induced protein 3 gene (TNFAIP3), on the other hand, inhibits nuclear factor $\mathrm{\kappa B}$-dependent signaling and, thus, prevents inflammation that is caused by multiple cytokines [83]. Genetic variation, therefore, could help to explain the increases in a wide range of cytokine responses in SLE. Recently, an interesting study evaluated changes in plasma concentrations of soluble mediators preceding clinically-defined disease flares in SLE. They found that patients with impending flare had significant alterations in a wide variety of soluble mediators at baseline with significantly higher levels of pro-inflammatory mediators, including Th1, Th2, and Th17-type cytokines, several weeks before clinical flare compared to clinically stable patients [84]. Levels of regulatory cytokines, including IL-10 and TGF- $\beta$ were higher in non-flare SLE patients, while baseline levels of soluble TNFRI, TNFRII, Fas, FasL, and CD40L were significantly greater in pre-flare patients. These findings support the idea that alterations in the balance between inflammatory and regulatory mediators may help identify patients at risk of disease flare and help decipher SLE pathogenic mechanisms [84]. Concerning the role of regulatory T cells in SLE, most studies point to a reduction in Treg cell number and function in SLE [85-87]. The role of Th17 cells has been described in the pathogenesis of SLE and several studies have reported an increase in Th17 cells and IL17 in SLE, and in particular with disease flare [88-90]. The Th17 and Treg ratio indicates that SLE is associated with a reduction in the levels and function of immunosuppressive Treg cells together with an increase in the pro-inflammatory Th17 cells [91]. Table 1. summarizes the relevant findings in cytokine imbalance and regulatory/effector cell makeup in UCTD and systemic autoimmune diseases. 


\section{In UCTD the Th17/Treg ratio signifies progression towards well-defined systemic autoimmune diseases}

As we have illustrated, in all these various patient groups with systemic autoimmune conditions, we could identify a circulating cytokine imbalance, clearly reflecting a proinflammatory milieu, moreover this particular cytokine imbalance and skewed pattern had the ability to promote the development of Th17 cells and the reduction in numbers/function of Tregs. UCTD is a very unique clinical entity, representing the initial stages of systemic autoimmune diseases. UCTD patients can have various clinical symptoms, specific for autoimmune diseases, along with immunoserological abnormalities, yet they do not meet the standard criteria for any well-defined systemic autoimmune disease [42-45]. The clinical symptoms and the presence of the autoantibodies in UCTD suggest that many of the same immunological abnormalities that play a role in different well-defined systemic autoimmune diseases can also be involved in UCTD. Taken together, these findings point to that the Th17/Treg imbalance can be a good marker of a subsequent transition of these patients towards well-defined systemic autoimmune diseases. Accordingly, we have assessed Th17 cells, as well as regulatory T cell subsets in patients with UCTD, and identified whether the imbalance of these immunologically important cell types contribute to the development of a subsequent definitive systemic autoimmune and rheumatic diseases [46]. In this study we found that the most common clinical manifestations of these UCTD patients were polyarthritis, Raynaud's phenomenon, and various skin symptoms, amongst others photosensitivity, malar rash and sclerodactily. Immunoserological abnormalities included positive ANA, ENA, RF, aSSA most frequently. The patients were followed-up for 5 years and changes of clinical activity, serological abnormalities, as well as the Th17 and Treg subsets were registered consecutively [46]. Th17 cells were found to be increased in UCTD 
patients, when compared to healthy individuals. Moreover, Th17 cells were further increased in UCTD patients that subsequentially developed systemic autoimmune/rheumatic disease. Interestingly, the Th17/Treg ratio gradually increased from controls through UCTD patients, reaching the highest values in those, whom eventually progressed into definitive systemic autoimmune disease. The evaluation of the Th17/Treg could distinguish between UCTD patients with, or without subsequent systemic autoimmune disease progression in a very early UCTD stage. Of immunoserological markers, anti-CCP clearly associated with Th17/Treg ratios in connection with subsequent RA development. Concerning SLE-progression, antiSSA showed an apparent positive correlation with Th17 cell numbers. RA showed the most associations with various regulatory-cell biomarkers in several time-points of the disease development.

\section{A skewed cytokine milieu can be responsible for the altered Th17/Treg balance in UCTD}

Since previous findings in systemic autoimmune and rheumatic diseases indicated a skewed cytokine milieu which could fuel the shift of the Th17/Treg balance, we have assessed a variety of circulating cytokines in patients with UCTD and found that the levels of IL-6, IL12, IL-17, IL-23 and IFN- $\gamma$ were pathologically increased with a parallel reduced level of IL10, which imbalance was normalized after alfacalcidiol treatment $[47,48]$. In parallel with the pro-inflammatory cytokine imbalance, increased Th17 with reduced Treg cell counts with a high Th17/Treg ratio was observed, which could be reverted by administering vitamin D to these patients $[47,48]$. These findings indicate that at a very early stage of systemic autoimmune disease development a shift of a cytokine imbalance, favoring a proinflammatory milieu is present, contributing to a biased Th17/Treg distribution, which further initiates and perpetuates tissue damage and the development of the disease-specific clinical 
symptoms. Presumably this functions as a reverberating cycle, as the tissue damage increases

disequilibrium. Taken these findings together it seems that the simultaneous, opposing effect of Th17 cells and Tregs has a strong impact on immune homeostasis, deciding and controlling the development of autoimmunity in these patients. Figure 1. summarizes the pathways and interconnections between tissue damage, skewed cytokine milieu and their role in the development of regulatory T cell and Th17 cell imbalance in autoimmune conditions.

\section{Concluding remarks}

Finally we should emphasize that besides the background Th17/Treg imbalance and cytokine dysequilibrium, a diverse antibody repertoire is present and may drive the development of various organ symptoms, leading to various autoimmune diseases. What determines the type of antibody produced and the type of systemic autoimmune disease developed? Why does the process stop for many patients at the UCTD stage without further progression? We believe that immune-regulatory responses should be followed in patients closely in the UCTD stage, and presumably if only temporary or mild dysfunction can be seen in this machinery, that may not cause severe organ damage. To answer these questions is obviously a huge task, in which knowledge of genetics, regulatory cell functions, Th17 cell development and assessment of the cytokine milieu should be involved.

Our findings support the idea that the pathological immuno-regulatory balance between Th17 cells and T cells with regulatory capacity at least partly drives the development of UCTD and its progression to definitive systemic autoimmune, rheumatic diseases. Therefore the assessment of these parameters in patients with UCTD may be a useful marker to identify high-risk individuals with a potential for disease progression. We believe that the disruption of this vicious cycle at a very early stage of the disease development (early UCTD 
stage) by the administration of immunomodulating agents (e.g. alfacalcidiol, vitamin D

derivates) can modulate the clinical picture, modify and decelerate the progression towards full-blown systemic autoimmune/rheumatic diseases.

\section{Conflict of interest statement}

The authors declare that they have no conflict of interest. 


\section{REFERENCES}

[1] Mosca M, Tani C, Carli L, Bombardieri S. Undifferentiated CTD: a wide spectrum of autoimmune diseases. Best Pract Res Clin Rheumatol. 2012;26:73-7.

[2] Mosca M, Tani C, Neri C, Baldini C, Bombardieri S. Undifferentiated connective tissue disease. Autoimmun Rev 2000;6:1-4.

[3] Williams HJ, Alarcon GS, Neuner R, et al. Early undifferentiated connective tissue disease. V. An inception cohort 5 years later: disease remissions and changes in diagnoses in well established and undifferentiated connective tissue diseases. J Rheumatol 1998;25:261-8. [4] Alarcon GS. Unclassified or undifferentiated connective tissue disease. Baillieres Best Pract Res Clin Rheumatol 2000;14:125-37.

[5] Williams HJ, Alarcon GS, Joks R, et al. Early undifferentiated connective tissue disease (CTD) VI: an inception cohort after 10 years: disease remissions and changes in diagnoses in well established and undifferentiated CTD. J Rheumatol 1999;26:816-25.

[6] LeRoy EC, Maricq HR, Kahaleh MB. Undifferentiated connective tissue syndromes. Arthritis Rheum 1980;23:341-3.

[7] Lleo A, Invernizzi P, Gao B, Podda M, Gershwin ME. Definition of human autoimmunity-autoantibodies versus autoimmune disease. Autoimmun Rev. 2010;9:A259-66.

[8] Abbas AK, Lohr J, Knoechel B, Nagabhushanam V. T cell tolerance and autoimmunity. Autoimmun Rev. 2004;3:471-5.

[9] Davies AJ. Immunological tolerance and the autoimmune response. Autoimmun Rev. 2008;7:538-43.

[10] Ermann J, Fathman CG. Autoimmune diseases: genes, bugs and failed regulation. Nat Immunol 2001;2:759-61. 
[11] Cooper GS, Miller FW, Pandey JP. The role of genetic factors in autoimmune disease: implications for environmental research. Environ Health Perspect 1999;107:693-700.

[12] Toda A, Piccirillo CA. Development and function of naturally occurring CD4+CD25+ regulatory cells. J Leukoc Biol 2006;80:458-70.

[13] Barath S, Sipka S, Aleksza M, et al. Regulatory T-cells in peripheral blood of patients with mixed connective tissue disease. Scand J Rheumatol 2006;35:300-4.

[14] Dejaco C, Duftner C, Grubeck-Loebenstein B, Schirmer M. Imbalance of regulatory T cells in human autoimmune diseases. Immunology 2006;117:289-300.

[15] Liu MF, Wang CR, Fung LL, Wu CR. Decreased CD4+CD25+ T-cells in peripheral blood of patients with systemic lupus erythematosus. Scand J Immunol 2004;59:198-202. [16] Szodoray P, Papp G, Horvath IF, Barath S, Sipka S, Nakken B, Zeher M. Cells with regulatory function of the innate and adaptive immune system in primary Sjögren's syndrome. Clin Exp Immunol. 2009;157:343-9.

[17] Valencia X, Yarboro C, Illei G, Lipsky PE. Deficient CD4+CD25high T regulatory cell function in patients with active systemic lupus erythematosus. J Immunol. 2007;178:2579-88. [18] Szodoray P, Nakken B, Barath S, Gaal J, Aleksza M, Zeher M, et al. Progressive divergent shifts in natural and induced T-regulatory cells signify the transition from undifferentiated to definitive connective tissue disease. Int Immunol 2008;20:971-9.

[19] Lee JH, Wang LC, Lin YT, Yang YH, Lin DT, Chiang BL. Inverse correlation between CD4 regulatory T-cell population and autoantibody levels in paediatric patients with systemic lupus erythematosus. Immunology 2006;117:280-6.

[20] Roncarolo MG, Gregori S, Battaglia M, Bacchetta R, Fleischhauer K. Levings M.K. Interleukin-10-secreting type 1 regulatory T cells in rodents and humans. Immunol Rev 2006;212:28-50. 
[21] Constant SL, Bottomly K. Induction of Th1 and Th2 CD4+ T-cell responses: the alternative approaches. Annu Rev Immunol 1997;15:297-322.

[22] Moore KW, de Waal Malefyt R, Coffman RL, O’Garra A. Interleukin 10 and the interleukin-10 receptor. Annu Rev Immunol. 2001;19:683-765.

[23] O'Garra A, Arai N. The molecular basis of T helper 1 and T helper 2 cell differentiation. Trends Cell Biol. 2000;10:542-50.

[24] Steinman L. A rush to judgment on Th17. J Exp Med. 2008;205:1517-22.

[25] Kotake S, Udagawa N, Takahashi N, Matsuzaki K, Itoh K, Ishiyama S, Saito S, Inoue K, Kamatani N, Gillespie MT, Martin TJ, Suda T. IL-17 in synovial fluids from patients with rheumatoid arthritis is a potent stimulator of osteoclastogenesis. J Clin Invest. 1999;103:134552.

[26] Hwang SY, Kim HY. Expression of IL-17 homologs and their receptors in the synovial cells of rheumatoid arthritis patients. Mol Cells. 2005;19:180-4.

[27] Shin MS, Lee N, Kang I. Effector T-cell subsets in systemic lupus erythematosus: update focusing on Th17 cells. Curr Opin Rheumatol. 2011;23:444-8.

[28] Chen DY, Chen YM, Wen MC, Hsieh TY, Hung WT, Lan JL. The potential role of Th17 cells and Th17-related cytokines in the pathogenesis of lupus nephritis. Lupus. 2012;21:138596.

[29] Lin X, Rui K, Deng J, Tian J, Wang X, Wang S, Ko KH, Jiao Z, Chan VS, Lau CS, Cao X, Lu L. Th17 cells play a critical role in the development of experimental Sjogren's syndrome. Ann Rheum Dis. 2014 Feb 26.

[30] Szodoray P, Alex P, Jonsson MV, Knowlton N, Dozmorov I, Nakken B, Delaleu N, Jonsson R, Centola M. Distinct profiles of Sjögren's syndrome patients with ectopic salivary gland germinal centers revealed by serum cytokines and BAFF. Clin Immunol. 2005;117:16876. 
[31] Valencia X, Lipsky PE. CD4+CD25+FoxP3+ regulatory T cells in autoimmune diseases. Nat Clin Pract Rheumatol. 2007;3:619-26.

[32] Yang J, Chu Y, Yang X, Gao D, Zhu L, Yang X, Wan L, Li M. Th17 and natural Treg cell population dynamics in systemic lupus erythematosus. Arthritis Rheum. 2009;60:147283.

[33] Kawanami T, Sawaki T, Sakai T, Miki M, Iwao H, Nakajima A, Nakamura T, Sato T, Fujita Y, Tanaka M, Masaki Y, Fukushima T, Hirose Y, Taniguchi M, Sugimoto N, Okazaki T, Umehara H. Skewed production of IL- 6 and TGF $\beta$ by cultured salivary gland epithelial cells from patients with Sjögren's syndrome. PLoS One. 2012;7:e45689.

[34] Tournadre A, Miossec P. Interleukin-17 in inflammatory myopathies. Curr Rheumatol Rep. 2012;14:252-6.

[35] Papp G, Horvath IF, Barath S, Gyimesi E, Vegh J, Szodoray P, Zeher M. Immunomodulatory effects of extracorporeal photochemotherapy in systemic sclerosis. Clin Immunol. 2012;142:150-9.

[36] Szodoray P, Alex P, Knowlton N, Centola M, Dozmorov I, Csipo I, Nagy AT, Constantin T, Ponyi A, Nakken B, Danko K. Idiopathic inflammatory myopathies, signified by distinctive peripheral cytokines, chemokines and the TNF family members B-cell activating factor and a proliferation inducing ligand. Rheumatology (Oxford). 2010;49:186777.

[37] Alex P, Szodoray P, Knowlton N, Dozmorov IM, Turner M, Frank MB, Arthur RE, Willis L, Flinn D, Hynd RF, Carson C, Kumar A, El-Gabalawy HS, Centola M. Multiplex serum cytokine monitoring as a prognostic tool in rheumatoid arthritis. Clin Exp Rheumatol. 2007;25:584-92. 
[38] Alex P, Szodoray P, Arthur E, Willis L, Hynd R, Flinn D, Centola M. Influence of intraarticular corticosteroid administration on serum cytokines in rheumatoid arthritis. Clin Rheumatol. 2007;26:845-8.

[39] Szodoray P, Alex P, Chappell-Woodward CM, Madland TM, Knowlton N, Dozmorov I, Zeher M, Jarvis JN, Nakken B, Brun JG, Centola M. Circulating cytokines in Norwegian patients with psoriatic arthritis determined by a multiplex cytokine array system. Rheumatology (Oxford). 2007;46:417-25.

[40] Osnes LT, Nakken B, Bodolay E, Szodoray P. Assessment of intracellular cytokines and regulatory cells in patients with autoimmune diseases and primary immunodeficiencies novel tool for diagnostics and patient follow-up. Autoimmun Rev. 2013;12:967-71.

[41] Szodoray P, Alex P, Brun JG, Centola M, Jonsson R. Circulating cytokines in primary Sjögren's syndrome determined by a multiplex cytokine array system. Scand J Immunol. 2004;59:592-9.

[42] Zeher M. Sjögren's syndrome. In: Sjögren's syndrome and associated disorders Eds.: Margit Zeher and Peter Szodoray. 2006. Research Signpost. Kerala, India, Transworld Research Network. p.p. 1-7.

[43] Szodoray P, Nakken B. Selected molecular aspects behind the clinical picture of Sjögren's syndrome. In: Sjögren's syndrome and associated disorders Eds.: Margit Zeher and Peter Szodoray. 2006. Research Signpost. Kerala, India, Transworld Research Network. p.p. 27-49.)

[44] Ciccia F, Guggino G, Giardina A, Ferrante A, Carrubbi F, Giacomelli R, Triolo G. The role of innate and lymphoid IL-22-producing cells in the immunopathology of primary Sjögren's syndrome. Expert Rev Clin Immunol. 2014;10:533-41.

[45] Garcíc-Carrasco M, Font J, Filella X, Cervera R, Ramos-Casals M, Sisó A, Aymamí A, Ballesta AM, Ingelmo M. Circulating levels of Th1/Th2 cytokines in patients with primary 
Sjögren's syndrome: correlation with clinical and immunological features. Clin Exp

Rheumatol 2001; 19: 411-15.

[46] Yao Y, Liu Z, Jallal B, Shen N, Rönnblom L. Type I Interferons in Sjögren's Syndrome. Autoimmun Rev. 2012 Nov 30.

[47] Jonsson R, Moen K, Vestrheim D, Szodoray P. Current issues in Sjögren's syndrome.

Oral Dis 2002;8:130-40.

[48] Szodoray P, Gal I, Barath S, Aleksza M, Horvath IF, Gergely P Jr, Szegedi G, Nakken B, Zeher M. Immunological alterations in newly diagnosed primary Sjögren's syndrome characterized by skewed peripheral T-cell subsets and inflammatory cytokines. Scand J Rheumatol. 2008;37:205-12.

[49] Kyriakidis NC, Kapsogeorgou EK, Tzioufas AG. A comprehensive review of autoantibodies in primary Sjögren's syndrome: Clinical phenotypes and regulatory mechanisms. J Autoimmun. 2013;S0896-8411:00145-5.

[50] Awada A, Nicaise C, Ena S, Schandéné L, Rasschaert J, Popescu I, Gangji V, Soyfoo MS. Potential involvement of the IL-33-ST2 axis in the pathogenesis of primary Sjogren's syndrome. Ann Rheum Dis. 2014 Jan 2.

[51] Szodoray P, Horvath IF, Papp G, Barath S, Gyimesi E, Csathy L, Kappelmayer J, Sipka S, Duttaroy AK, Nakken B, Zeher M. The immunoregulatory role of vitamins A, D and E in patients with primary Sjogren's syndrome. Rheumatology (Oxford). 2010;49:211-7. [52] LeRoy EC, Medsger TA Jr. Criteria for the classification of early systemic sclerosis. J Rheumatol 2001;28:1573-6.

[53] Lei W, Luo Y, Lei W, Luo Y, Yan K, Zhao S. Abnormal DNA methylation in CD4+ T cells from patients with systemic lupus erythematosus, systemic sclerosis, and dermatomyositis. Scand J Rheumatol 2009;38:369-74. 
[54] Horikawa M, Hasegawa M, Komura K, Hayakawa I, Yanaba K, Matsushita T, Abnormal natural killer cell function in systemic sclerosis: altered cytokine production and defective killing activity. J Invest Dermatol 2005;125:731-7.

[55] Riccieri V, Parisi G, Spadaro A, Scrivo R, Barone F, Moretti T. Reduced circulating natural killer T cells and gamma/delta T cells in patients with systemic sclerosis. J Rheumatol 2005;32:283-6.

[56] Slobodin G, Ahmad MS, Rosner I, Peri R, Rozenbaum M, Kessel A. Regulatory T cells (CD4(+)CD25(bright)FoxP3(+)) expansion in systemic sclerosis correlates with disease activity and severity. Cell Immunol 2010;261:77-80.

[57] Banica L, Besliu A, Pistol G, Stavaru C, Ionescu R, Forsea AM. Quantification and molecular characterization of regulatory $\mathrm{T}$ cells in connective tissue diseases. Autoimmunity 2009;42:41-9.

[58] Murata M, Fujimoto M, Matsushita T, Hamaguchi Y, Hasegawa M, Takehara K, Clinical association of serum interleukin-17 levels in systemic sclerosis: is systemic sclerosis a Th17 disease? J Dermatol Sci 2008;50:240-2.

[59] Deleuran B, Abraham DJ. Possible implication of the effector CD4+ T-cell subpopulation TH17 in the pathogenesis of systemic scleroderma. Nat Clin Pract Rheumatol 2007;3:682-3.

[60] Sakkas LI, Platsoucas CD. Is systemic sclerosis an antigen-driven T cell disease? Arthritis Rheum 2004;50:1721-33.

[61] Papp G, Horvath IF, Barath S, Gyimesi E, Sipka S, Szodoray P, Zeher M. Altered T-cell and regulatory cell repertoire in patients with diffuse cutaneous systemic sclerosis. Scand $\mathbf{J}$ Rheumatol. 2011;40:205-10. 
[62] Papp G, Horvath IF, Barath S, Gyimesi E, Vegh J, Szodoray P, Zeher M.

Immunomodulatory effects of extracorporeal photochemotherapy in systemic sclerosis. Clin Immunol. 2012;142:150-9.

[63] Papp G, Barath S, Szegedi A, Szodoray P, Zeher M. The effects of extracorporeal photochemotherapy on $\mathrm{T}$ cell activation and regulatory mechanisms in patients with systemic sclerosis. Clin Rheumatol. 2012;31:1293-9.

[64] GC Sharp, WS Irvin, EM Tan, RG Gould, HR Holman. Mixed connective tissue disease -an apparently distinct rheumatic disease syndrome associated with a specific antibody to an extractable nuclear antigen. Am J Med 1972;52:148-59.

[65] GC Sharp. Diagnostic criteria for classification of MCTD. In: Kasukawa R, Sharp GC, editors. Mixed connective tissue disease and antinuclear antibodies. Amsterdam: Elsevier Science Publishers BV; 1987:23-33.

[66] Kasukawa R, Tojo T, Miyawaki S. Preliminary diagnostic criteria for classification of mixed connective tissue disease. In: Kasukawa R, Sharp GC, editors. Mixed connective tissue disease and antinuclear antibodies. Amsterdam: Elsevier Science Publishers BV; 1987:41-7. [67] Hameenkorpi R, Ruuska P, Forsberg S, Tiilikainen R, Makitalo R, Hakula M. More evidence of distinctive features of mixed connective tissue disease. Scand J Rheumatol $1993 ; 22: 63-8$.

[68] Smolen JS, Steiner G. Mixed connective tissue disease: to be or not to be? Arthritis Rheum 1998;41:768-77.

[69] Hoffman RW, Greidinger EL. Mixed connective tissue disease. Curr Opin Rheumatol 2000;12:386-90.

[70] Maddison PJ. Mixed connective tissue disease: overlap syndromes. Baillieres Best Pract Res Clin Rheumatol 2000;14:111-24. 
[71] Burdt MA, Hoffman RW, Deutscher SL, Wang GS, Johnson JC, Sharp GC. Long-term outcome in mixed connective tissue disease. Arthritis Rheum 1999;42:899-909.

[72] Bodolay E, Aleksza M, Antal-Szalmás P, Végh J, Szodoray P, Soltész P, Szegedi A, Szekanecz Z. Serum cytokine levels and type 1 and type 2 intracellular T cell cytokine profiles in mixed connective tissue disease. J Rheumatol. 2002;29:2136-42.

[73] Baráth S, Sipka S, Aleksza M, Szegedi A, Szodoray P, Végh J, Szegedi G, Bodolay E. Regulatory T cells in peripheral blood of patients with mixed connective tissue disease. Scand J Rheumatol. 2006;35:300-4.

[74] Hajas A, Szodoray P, Barath S, Sipka S, Rezes S, Zeher M, Sziklai I, Szegedi G, Bodolay E. Sensorineural hearing loss in patients with mixed connective tissue disease: immunological markers and cytokine levels. J Rheumatol. 2009;36:1930-6.

[75] Hajas A, Sandor J, Csathy L, Csipo I, Barath S, Paragh G, Seres I, Szegedi G, Shoenfeld Y, Bodolay E. Vitamin D insufficiency in a large MCTD population. Autoimmun Rev. 2011;10:317-24.

[76] Tsokos GC. Systemic lupus erythematosus. N Eng1 J Med. 2011;365:2110-21.

[77] Merola J, Bermas B, Lu B, Karlson E, Massarotti E, Schur P, Costenbader K. Clinical manifestations and survival among adults with (SLE) according to age at diagnosis. Lupus. 2014 Mar 7.

[78] Heinlen LD, McClain MT, Merrill J, Akbarali YW, Edgerton CC, Harley JB, James JA. Clinical criteria for systemic lupus erythematosus precede diagnosis, and associated autoantibodies are present before clinical symptoms. Arthritis Rheum. 2007;56:2344-51. [79] Aringer M, Smolen JS. Tumour necrosis factor and other proinflammatory cytokines in systemic lupus erythematosus: a rationale for therapeutic intervention. Lupus. 2004;13:344-7. [80] Rönnblom L, Elkon KB. Cytokines as therapeutic targets in SLE. Nat Rev Rheumatol. 2010;6:339-47. 
[81] Niewold TB, Kelly JA, Flesch MH, Espinoza LR, Harley JB, Crow MK. Association of the IRF5 risk haplotype with high serum interferon-alpha activity in systemic lupus erythematosus patients. Arthritis Rheum. 2008;58:2481-7.

[82] Kariuki SN, Kirou KA, MacDermott EJ, Barillas-Arias L, Crow MK, Niewold TB. Cutting edge: autoimmune disease risk variant of STAT4 confers increased sensitivity to IFNalpha in lupus patients in vivo. J Immunol. 2009;182:34-8.

[83] Vereecke L, Beyaert R, van Loo G. The ubiquitin-editing enzyme A20 (TNFAIP3) is a central regulator of immunopathology. Trends Immunol. 2009;30:383-91.

[84] Munroe ME, Vista ES, Guthridge JM, Thompson LF, Merrill JT, James JA. Proinflammatory adaptive cytokines and shed tumor necrosis factor receptors are elevated preceding systemic lupus erythematosus disease flare. Arthritis Rheumatol. 2014 Feb 27. [85] Barath S, Aleksza M, Tarr T, Sipka S, Szegedi G, Kiss E. Measurement of natural (CD4+CD25high) and inducible (CD4+IL-10+) regulatory T cells in patients with systemic lupus erythematosus. Lupus 2007;16:489-496.

[86] Barath S, Soltesz P, Kiss E, Aleksza M, Zeher M, Szegedi G, Sipka S. The severity of systemic lupus erythematosus negatively correlates with the increasing number of CD4+CD25(high)FoxP3+ regulatory T cells during repeated plasmapheresis treatments of patients. Autoimmunity 2007;40:521-528.

[87] Bonelli M, Savitskaya A, von Dalwigk K, Steiner CW, Aletaha D, Smolen JS, Scheinecker C. Quantitative and qualitative deficiencies of regulatory T cells in patients with systemic lupus erythematosus (SLE). Int Immunol 2008;20:861-868.

[88] Wong CK, Lit LC, Tam LS, Li EK, Wong PT, Lam CW. Hyperproduction of IL-23 and IL-17 in patients with systemic lupus erythematosus: implications for Th17-mediated inflammation in auto-immunity. Clin Immunol 2008; 127:385-393. 
[89] Wong CK, Ho CY, Li EK, Lam CW. Elevation of proinflammatory cytokine (IL-18, IL17, IL-12) and Th2 cytokine (IL-4) concentrations in patients with systemic lupus erythematosus. Lupus 2000; 9:589-593.

[90] Doreau A, Belot A, Bastid J, Riche B, Trescol-Biemont MC, Ranchin B, Fabien N, Cochat P, Pouteil-Noble C, Trolliet P, Durieu I, Tebib J, Kassai B, Ansieau S, Puisieux A, Eliaou JF, Bonnefoy-Berard N. Interleukin 17 acts in synergy with B cell-activating factor to influence B cell biology and the pathophysiology of systemic lupus erythematosus. Nat Immunol 2009; 10:778-785.

[91] Alunno A, Bartoloni E, Bistoni O, Nocentini G, Ronchetti S, Caterbi S, Valentini V, Riccardi C, Gerli R. Balance between regulatory T and Th17 cells in systemic lupus erythematosus: the old and the new. Clin Dev Immunol 2012; 2012:823085.

[92] Bodolay E, Csiki Z, Szekanecz Z, Ben T, Kiss E, Zeher M, Szücs G, Dankó K, Szegedi G. Five-year follow-up of 665 Hungarian patients with undifferentiated connective tissue disease (UCTD). Clin Exp Rheumatol. 2003;21:313-20.

[93] Mosca M, Tani C, Vagnani S, Carli L, Bombardieri S. The diagnosis and classification of undifferentiated connective tissue diseases. J Autoimmun. 2014;48-49:50-2.

[94] Mosca M, Tani C, Talarico R, Bombardieri S. Undifferentiated connective tissue diseases (UCTD): simplified systemic autoimmune diseases. Autoimmun Rev. 2011;10:2568.

[95] Vaz CC, Couto M, Medeiros D, Miranda L, Costa J, Nero P, Barros R, Santos MJ, Sousa E, Barcelos A, Inês L. Undifferentiated connective tissue disease: a seven-center crosssectional study of 184 patients. Clin Rheumatol. 2009;28:915-21.

[96] Szodoray P, Nakken B, Barath S, Csipo I, Nagy G, El-Hage F, Osnes LT, Szegedi G, Bodolay E. Altered Th17 cells and Th17/regulatory T-cell ratios indicate the subsequent 
conversion from undifferentiated connective tissue disease to definitive systemic autoimmune disorders. Hum Immunol. 2013;74:1510-8.

[97] Zold E, Szodoray P, Kappelmayer J, Gaal J, Csathy L, Barath S, Gyimesi E, Hajas A, Zeher M, Szegedi G, Bodolay E. Impaired regulatory T-cell homeostasis due to vitamin D deficiency in undifferentiated connective tissue disease. Scand J Rheumatol. 2010;39:490-7. [98] Zold E, Szodoray P, Nakken B, Barath S, Kappelmayer J, Csathy L, Hajas A, Sipka S, Gyimesi E, Gaal J, Barta Z, Hallay J, Szegedi G, Bodolay E. Alfacalcidol treatment restores derailed immune-regulation in patients with undifferentiated connective tissue disease. Autoimmun Rev. 2011;10:155-62. 


\section{FIGURE LEGENDS}

Figure 1. Pathways and interconnections between tissue damage, skewed cytokine milieu and their role in the development of regulatory $\mathrm{T}$ cell and Th17 cell imbalance in systemic autoimmune diseases. 
TABLES

Table 1. Skewed cytokine balance, cellular and immunoregulatory abnormalities in

\section{UCTD and various systemic autoimmune diseases}

\begin{tabular}{|c|c|c|c|}
\hline & $\begin{array}{l}\text { Disease classification/ } \\
\text { definition }\end{array}$ & $\begin{array}{l}\text { Characteristic cytokine } \\
\text { imbalance }\end{array}$ & $\begin{array}{l}\text { Cellular and } \\
\text { Immunoregulatory defects }\end{array}$ \\
\hline $\begin{array}{l}\text { Undifferentiated } \\
\text { Connective Tissue Disease } \\
\text { (UCTD) }\end{array}$ & $\begin{array}{l}\text { - Forerunner of well } \\
\text { established systemic } \\
\text { autoimmune diseases } \\
\text { - UCTD shares clinical and } \\
\text { serological manifestations } \\
\text { with definite connective tissue } \\
\text { diseases, but not fulfilling any } \\
\text { of the existing classification } \\
\text { criteria }\end{array}$ & $\begin{array}{l}\text {-Increased serum levels of } \\
\text { IL-6, IL-12, IL-17, IL-23 } \\
\text { and IFN- } \gamma \\
\text {-Diminished IL-10 }\end{array}$ & $\begin{array}{l}\text {-percentage and absolute number } \\
\text { of natural Tregs are diminished } \\
\text {-CD4+IL10+, inducible Treg } \\
\text { increased } \\
\text {-progressive divergent shift } \\
\text { between natural and inducible } \\
\text { Tregs signify disease } \\
\text { progression }\end{array}$ \\
\hline Sjögren’s syndrome (pSS) & $\begin{array}{l}\text { - pSS is a common systemic } \\
\text { autoimmune disease that } \\
\text { primarily affects the exocrine } \\
\text { glands and leads to decreased } \\
\text { lachrymal and salivary } \\
\text { secretion. } \\
\text { - other systemic symptoms, } \\
\text { denoted as extraglandular } \\
\text { manifestations can also be } \\
\text { found in a subset of patients }\end{array}$ & $\begin{array}{l}\text {-Elevated levels of IL-17 } \\
\text { in the serum and salivary } \\
\text { glands } \\
\text {-High serum IFN- } \gamma \text {, } \\
\text { decreased IL-10 } \\
\text {-IL-1b, IL-2, IL-6, IL-15, } \\
\text { IFN- } \gamma, \text { CCL4 are } \\
\text { increased in patients } \\
\text {-IL-4, IL-10, GM-CSF, } \\
\text { IFN-a, IFN- } \gamma, \text { CCL3, } \\
\text { CCL11, BAFF signifies } \\
\text { ectopic germinal center } \\
\text { positive patients }\end{array}$ & $\begin{array}{l}\text {-Increased proportion of } \\
\text { activated T cells and memory } \\
\text { CD4+/CD8+ } \\
\text {-Elevated NK, NKT cells }\end{array}$ \\
\hline Systemic sclerosis (SSc) & $\begin{array}{l}\text { - chronic autoimmune disease } \\
\text { with vascular dysfunctions and } \\
\text { fibrosis of the skin, vessel } \\
\text { wall, musculoskeletal system } \\
\text { and certain internal organs } \\
\text { - commonly divided into } \\
\text { limited and diffuse cutaneous } \\
\text { forms, based on the extent of } \\
\text { skin involvement } \\
\text { - in diffuse cutaneous SSc, the } \\
\text { rapid fibrotic processes result } \\
\text { in progressive deterioration } \\
\text { and atrophy of the skin and } \\
\text { involved internal organs }\end{array}$ & $\begin{array}{l}\text {-Serum IL-17 elevated } \\
\text {-Low serum levels of IL- } \\
10\end{array}$ & $\begin{array}{l}\text {-Th17 proportion increased } \\
\text {-Tregs diminished (both natural } \\
\text { and inducible subsets) } \\
\text {-weaker Treg suppressor } \\
\text { function } \\
\text {-altered Th1/Th2 balance } \\
\text {-increased activated T-cell } \\
\text { frequency } \\
\text {-shift towards central memory } \\
\text { phenotype } \\
\text {-NK, NKT abnormalities }\end{array}$ \\
\hline $\begin{array}{l}\text { Mixed Connective Tissue } \\
\text { Disease (MCTD) }\end{array}$ & $\begin{array}{l}\text { - systemic autoimmune, } \\
\text { inflammatory disorder, } \\
\text { characterized by the } \\
\text { simultaneous damage of } \\
\text { multiple organs. } \\
\text { - the most common symptoms } \\
\text { are polyarthritis, the swelling } \\
\text { of the hands and fingers, } \\
\text { Raynaud's phenomenon, } \\
\text { myositis, esophageal } \\
\text { dysmotility, pulmonary } \\
\text { arterial hypertension and } \\
\text { interstitial lung disease }\end{array}$ & $\begin{array}{l}\text {-Both type I and type II } \\
\text { cytokines are increased }\end{array}$ & $\begin{array}{l}\text {-Diminished natural Treg } \\
\text { frequency } \\
\text { - CD4+IL10+, inducible Treg } \\
\text { increased } \\
\text {-IFN- } \gamma \text {-producing and IL-4- } \\
\text { producing CD8+ T cells are } \\
\text { increased } \\
\text {-diminished Th2 } \\
\text {-IL-10+CD4+ and IL-10+CD8+ } \\
\text { T-cells are increased }\end{array}$ \\
\hline
\end{tabular}




\begin{tabular}{|c|c|c|c|}
\hline $\begin{array}{l}\text { Systemic Lupus } \\
\text { Erythematosus }\end{array}$ & $\begin{array}{l}\text { - commonly affects women in } \\
\text { child-bearing years } \\
\text { - heterogeneous systemic } \\
\text { autoimmune disease, which } \\
\text { encompasses mild to moderate } \\
\text { forms, and also severe, } \\
\text { progressive variants } \\
\text { - several organs can be } \\
\text { affected, amongst others the } \\
\text { cardio-vascular, } \\
\text { musculoskeletal, } \\
\text { hematopoietic, excretory, } \\
\text { respiratory and nervous } \\
\text { systems }\end{array}$ & $\begin{array}{l}\text {-Increased IL-17 } \\
\text { - BAFF/BLyS, TNF- } \alpha \text {, } \\
\text { IFN- } \alpha, \text { IFN- } \gamma, \text { IL-12, IL- } \\
23, \text { IL-18, IL-6, IL-10 } \\
\text { play a role in the } \\
\text { pathogenesis } \\
\text {-IL-10 and TGF- } \beta \text { is } \\
\text { reduced, while soluble } \\
\text { TNFRI, TNFRII, Fas, } \\
\text { FasL, and CD40L is } \\
\text { elevated in patients before } \\
\text { disease flare }\end{array}$ & $\begin{array}{l}\text {-Reduced numbers of FoxP3+ } \\
\text { natural Tregs } \\
\text {-Increased ratio of Th17 plays a } \\
\text { role in lupus development and } \\
\text { lupus nephritis as well in } \\
\text { patients with disease flares } \\
\text {-Increased Th17/Treg ratio }\end{array}$ \\
\hline
\end{tabular}




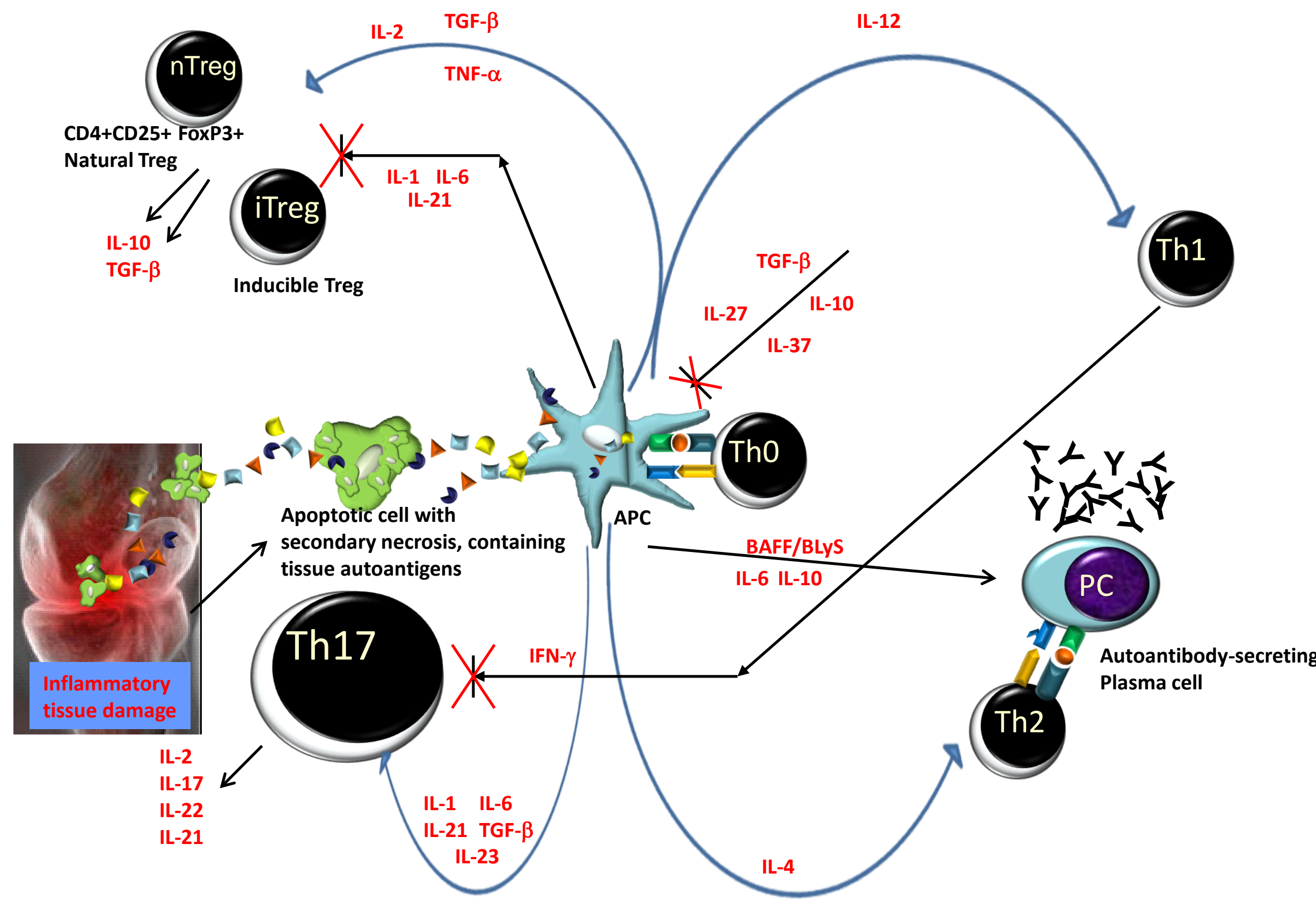

